\title{
CHARACTERISTICS OF OSTRICH MEAT IN MANUFACTURING SAUSAGE IN COMPARISON WITH BEEF
}

\author{
Yasir Hilal ELHASHMI ${ }^{\star}$, Sulafa Yousif FALIH and Mohammed Elkhatim Ibrahim ABDALMAGEED \\ Department of Meat Production and Technology, Faculty of Animal Production, University of Gezira, Al-Managil, P.O.Box 20, Sudan \\ Email: yahilal@gmail.com; (DORCiD: 0000-0002-7298-6169 \\ Supporting Information
}

\begin{abstract}
Ostrich meat has become one of the most popular meat around the world. The objectives of this study are to evaluate the quality characteristics of processed meat, compared to products made from beef. The Ostrich and beef meat was prepared and stored frozen. Sausage was processed in laboratory and analyzed for chemical composition (crude protein, moisture, fat and ash). Physical properties include Water-holding capacity (WHC), cooking loss and microbiological analysis were done. The findings of this study revealed that, chemical composition of sausage from ostrich and beef had highly significant differences in moisture, crude protein, lipids and ash among all types of products. Physical attribute of sausage revealed that, there were highly significant differences among all types of products. The microbiological in sausage observed that, the highly significant differences in E. coli, staphylococcus aurous, total coli form, yeast and mold and total viable count but was not significant differences in Pseudomonas among all types of sausage. The study recommended that ostrich meat can be used on manufacturing of meat as an alternative to beef meat in limited amount.
\end{abstract}

Keywords: Animal Product, Meat, Ostrich, Processing, Sausage.

\section{INTRODUCTION}

Today, the world faces the problem of shortage in food supply, which creates the malnutrition problem and its consequences in the developing countries, processed meat from non- conventional meat sources like wild animals spatially Ostrich can used as part of solving the problem (Food and Agriculture Organization, 2011). Sausage is prepared food usually made from ground meat, animal fat, salt, spices and typically backed in a casing (Steven et al., 2019). Commonly, there are six types of sausages: fresh sausage, uncooked smoked sausage, cooked smoke sausage, and cooked sausage, dry and semi-dry sausage (Hasan Hussein et al., 2019; Steven et al., 2019).

According to Hoffman et al. (2005) meat from ostriches fed a standard diet contains $21.65,1.95$ and $1.2 \%$ protein, fat and ash, respectively. Ostrich meat is recommended for overweight people and for those who suffer from coronary heart disease (Cooper 1999; Antunes et al., 2018; Zdanowska-Sąsiadek et al., 2018). Thus, during cooking, the fat content increase and causes decrease in moisture (Sales et al., 1999). Compared with other species, e.g. chicken and beef, ostrich meat shows a beneficial fatty acids profile (Sales and Horbanczuk, 1998).

Atef et al. (2015) were found that, the chemical composition of beef sausage was: moisture (65.31\%) crud fat $20 \%$, ash $9.5 \%$ and crud protein $61.28 \%$ when investigated effect of Arak Stems Extracts on chemical characteristics bacteria activity evaluation of beef sausage products. Alamin (2015) studied sausage some quality attribute, she found that water holding capacity of beef sausage was $1.06 \%$ and the cooking loss was (22.02\%). Ibrahim, (2008) reported that Beef Sausage water holding capacity was $59.55 \%$ and cooking loss was $17 \%$. Atef et al. (2015) found that the microbial count of beef sausage was: E. coli: N.D, Salmonella: N.D, staphylococcus aureus: N.D, Coli form group D and total viable count was (6.15\%). The objectives of this study are to evaluate the quality characteristics of processed meat, compared to products made from beef and meat with other meat animals.

\section{MATERIALS AND METHODS}

The ostrich and beef meat was obtained and then stored and frozen. The additional materials needed in the formulation were spices, salt, potatoes, onion, garlic, Chick Peas, milk Powder, Bread crumb and Rice.

Two types of sausage (Ostrich and beef) were produced. The minced meat (ostrich, beef) was mixed with other ingredients (Beef fat, chick peas, rice, water, salt, skim Milk powder and seasoning mixture). The mixture was stuffed into prepared sheep intestine casing and formed into fingers of about 5-7 cm in length. Samples of the two types of sausage were analyzed to evaluate the chemical composition, Physical composition, microbial load and sensory evaluation. 
Proximate chemical composition for determination of moisture, crude protein, fat (ether extract) and ash of the sample was done according to A.O.A.C. (2002). The cooking loss was determined according to Honkel (1998) method. WHC determination was done according to the method of Babiker and Lawrie (1983). Microbial load on (sausage) was assessed, it includes the identification of total viable counts, coliforms, yeast and mould, pseudomonas, E. coli, Salmonella ssp, Staphylococcus aureus.

\section{Statistical analysis}

All statistical analysis was done by using the computer with SPSS program Ver. $(17,2008)$ and Duncan multiple range tests was used to detect difference between means (Snedecor and Cochran, 1980).

\section{RESULTS AND DISCUSSION}

Table 1 showed the chemical composition of sausage from ostrich and beef. The moisture of sausages processed from ostrich and beef were $66.99 \%$ and $68.95 \%$ respectively. There were highly significant differences in moisture (PS 0.01$)$ among all type of sausages. The higher moisture was found in beef sausage, while the lower moisture was recorded in ostrich sausage. In this study the moisture content was greater than that of Atef et al. (2015), who reported that moisture of beef sausage was (65.31\%) and less than Mohammed (2009) who observed that moisture of beef sausage was (72.43\%) and disagree with Ibrahim (2008) who recorded that moisture of beef sausage was (57.56\%).

The protein of sausages processed from ostrich and beef were $19.25 \%$ and $14.00 \%$ respectively. There were highly significant differences $(P \leq 0.01)$ in protein among the products. The higher protein content was observed in ostrich sausage, while the lower protein was found in beef sausage. The findings were lesser than Atef et al, (2015) who were pointed out that the crude protein (CP) of beef sausage was $(61.28 \%)$ and agreement with Ibrahim (2008) who found that CP of beef sausage (14.09\%), but disagree with Mohammed (2009) who stated out that CP of beef sausage was (17.55\%).

The ether extract of fat of sausage processed from ostrich and beef were $1.83 \%, 0.83 \%$ respectively. There were highly significant differences $(P \leq 0.01)$ in total energy expenditure (E.E) of fat among all type of the product. The higher E.E of fat content was observed in ostrich sausage. The findings were very lower than Atef et al. (2015) who found that Fat of beef sausage was $20 \%$, also lesser than Mohammed (2009) who pointed out that Fat of beef sausage was (7.79\%) And disagree with Ibrahim (2008) who reported that Fat of beef sausage was (16.49\%).

Ash content of sausage processed from ostrich and beef were $2.44 \%$ and $2.04 \%$ respectively. There were highly significant differences $(P \leq 0.01)$ in ash between ostrich sausage and beef sausage. The higher ash was found in ostrich sausage. This finding was lower than that of Atef et al. (2015) who found that Ash of beef sausage was (9.5\%), but agreement with Mohammed (2009) who stated out that Ash beef sausage was (2.02\%) and greater that Ibrahim (2008) who observed that Ash beef sausage was (1.07\%).

\section{Table 1 - Average values (Means \pm SE) of chemical composition for sausage of ostrich and beef.}

\begin{tabular}{|c|c|c|c|c|}
\hline \multirow{2}{*}{ Variables } & \multirow{2}{*}{ Over All } & \multicolumn{2}{|c|}{ Sausage } & \multirow{2}{*}{ Sig. } \\
\hline & & Ostrich & Beef & \\
\hline Moisture \% & $68.47 \pm 0.29$ & $66.99 \pm 0.41^{b}$ & $68.95 \pm 0.41^{\mathrm{a}}$ & $\star *$ \\
\hline Crude Protein \% & $16.63 \pm 0.004$ & $19.25 \pm 0.006^{a}$ & $14.00 \pm 0.006^{b}$ & $\star *$ \\
\hline Ether. Extract \% & $1.33 \pm 0.004$ & $1.83 \pm 0.006^{a}$ & $0.83 \pm 0.006^{b}$ & $\star *$ \\
\hline Ash \% & $2.24 \pm 0.01$ & $2.44 \pm 0.02^{a}$ & $2.04 \pm 0.02^{b}$ & $\star *$ \\
\hline
\end{tabular}

Table 2 showed some physical properties of sausage from ostrich and beef. The water holding capacity of sausage processed from ostrich and beef were $2.24,3.35$ respectively. There were highly significant differences $(P \leq 0.01)$ in water holding capacity content among sausage. The higher water holding capacity content was observed in beef sausage. The findings were greater than Alamin (2015) who found that the water holding capacity of beef sausage was (1.06\%) when was studied sausage some quality attribute, but lower than Ibrahim (2008) who stated out that the water holding capacity of beef sausage was (59.55\%).

Cooking loss of sausage processed from ostrich and beef were $32.41,39.95$ respectively. There were highly significant differences $(P \leq 0.05)$ in cooking loss between ostrich and beef sausage. The higher cooking loss was found to be in beef sausage. The findings were very higher than Alamin (2015) whom reported that cooking loss of beef sausage was (22.02\%) when investigated some quality attribute, also greater than Ibrahim (2008) who found that cooking loss of beef sausage was (17\%).

Table 3 showed the microbiological properties for sausage of ostrich and beef $E$. coli of sausage processed from

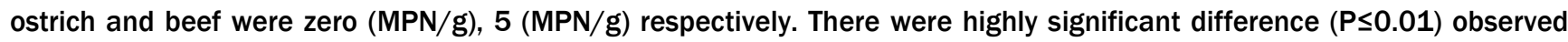


among ostrich and beef sausage. The higher E. coli content was found to be in beef sausage. The finding was in line with Hamad (2010) who found that E. coli count of beef sausage was (20\%) when studied prevalence of Escherichia. Coli, salmonella and Staphylococcus aureus and processed meat in Khartoum State, but disagree with Atef et al. (2015), who was not detected $E$. coli bacteria.

Table 2 - Average values of some physical properties for sausage of Ostrich and beef (Means \pm SE).

\begin{tabular}{|c|c|c|c|c|}
\hline \multirow{2}{*}{ Variables } & \multirow{2}{*}{ Over All } & \multicolumn{2}{|c|}{ Sausage } & \multirow{2}{*}{ Sig. } \\
\hline & & Ostrich & Beef & \\
\hline Water holding capacity & $2.80 \pm 0.004$ & $2.24 \pm 0.006^{b}$ & $3.35 \pm 0.006^{a}$ & ** \\
\hline Cooking Loss & $36.18 \pm 0.004$ & $32.41 \pm 0.006^{b}$ & $39.95 \pm 0.006^{a}$ & ** \\
\hline
\end{tabular}

Table 3 -Average values (Means \pm SE) of microbiological properties for sausage of Ostrich and Beef

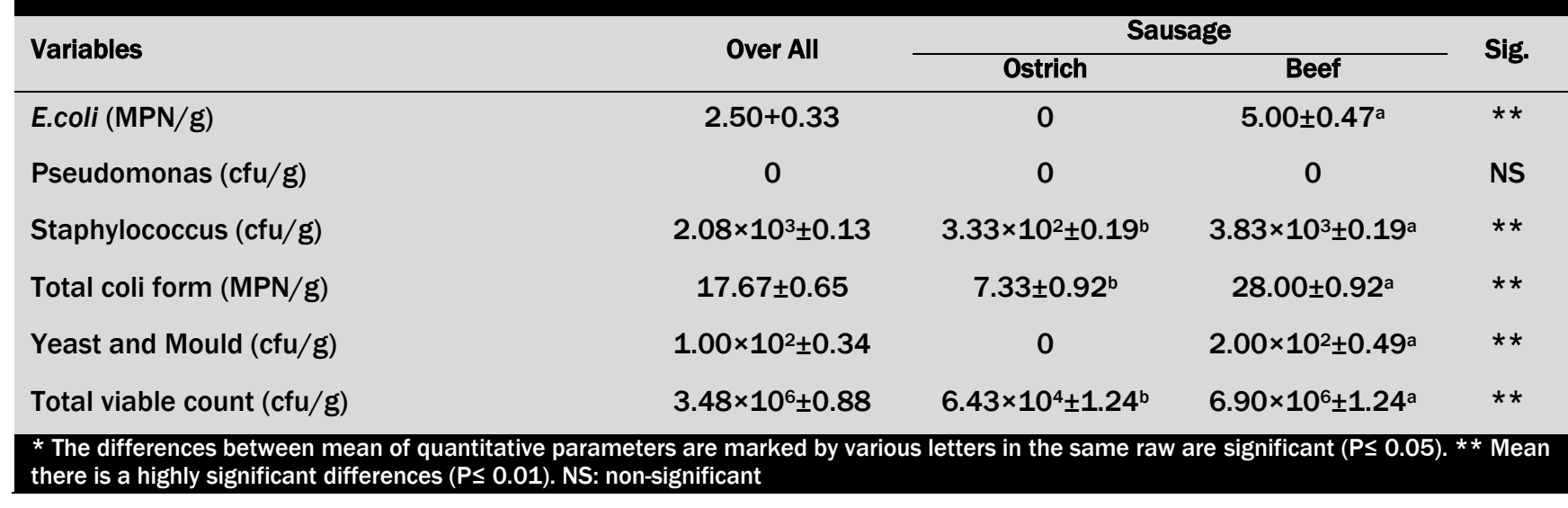

Table 4 - Salmonella presence in sausage from ostrich and beef

\begin{tabular}{lcc|ccc} 
& \multicolumn{3}{c}{ Sausage } \\
\cline { 2 - 6 } Detection of salmonella & $\mathrm{N}$ & Ostrich & \multicolumn{2}{c}{ Beef } & N \\
\hline Positive & 0 & 0 & 1 & 33.3 \\
Negative & 3 & 100 & 2 & 66.7 \\
Total & 3 & 100 & 3 & 100 \\
\hline
\end{tabular}

The pseudo of sausage processed from ostrich and beef were zero (CFU/g), zero (CFU/g) respectively. There were no significant differences in Pseudomonas count observed among ostrich and beef sausage. The Staphylococcus of sausage processed from ostrich and beef were $3.33 \times 10^{2}(\mathrm{CFU} / \mathrm{g}), 3.83 \times 10^{3}$ (CFU/g) respectively. There were highly significant difference $(P \leq 0.01)$ in Staphylococcus among ostrich and beef sausage. While beef sausage recorded the highest content of Staphylococcus while the lowest content of Staphylococcus was found in ostrich sausage. The findings were in line with Hamad (2010) who stated out that staphylococcus of beef sausage was (52\%) when investigated prevalence of Escherichia. Coli, salmonella and Staphylococcus aureus and processed meat in Khartoum State, while Atef et al. (2015) were not detected staphylococcus in beef sausage when studied the effect of Arak Stems Extracts on chemical characteristics bacteria activity and sensory evaluation of beef sausage products. The total coli form of sausage processed from different type of meat (ostrich and beef) 7.33 (MN/g), 28 (MPN/g) respectively.There were significant differences $(P \leq 0.01)$ in total coli form content among sausages. The highest content of total coli form was found to be in beef sausage. The results in the present study were agreement with Atef et al. (2015), who found that total coli form count in beef sausage was detected when studied the effect of arak stems extracts on chemical characteristics bacteria activity and sensory evaluation of beef sausage products.

The yeast and moulds of sausage processed from ostrich and beef were zero (CFU/g), $2 \times 10^{2}$ (CFU/g) respectively. There were highly significant differences $(P \leq 0.01)$ in yeast and moulds between (ostrich and beef) sausage. The highest yeast and moulds content was found in beef sausage, while was not found in ostrich sausage. The total viable count of bacteria for sausage processed from ostrich and beef were $6.43 \times 10^{5}(\mathrm{CFU} / \mathrm{g}), 6.90 \times 10^{7}(\mathrm{cFU} / \mathrm{g})$ respectively. There were highly significant differences $(\mathrm{P} \leq 0.01)$ in total viable count among all type of sausage. The higher content of total viable count was found in beef sausage, while the lower content of total viable count was recorded in ostrich sausage. 
The findings of study were greater than Atef et al. (2015) who pointed out that the total coli from count in beef sausage was $6.25 \mathrm{cfu} / \mathrm{g}$ when studied the effect of arak stems extracts on chemical characteristics bacteria activity and sensory evaluation of beef sausage products. Table 4 showed that the detection of salmonella sausage processed from ostrich was $0(\mathrm{~N})-0 \%$ positive and $3(\mathrm{~N})-100 \%$ negative. While beef sausage was $1(\mathrm{~N})-33.3 \%$ positive and $2(\mathrm{~N})-66.7 \%$ negative. There was no significant differences found among detection of salmonella for all types of sausage. The findings were disagree with Atef et al. (2015), who found that detection of salmonella in beef sausage was not detected but was agreement with Hamad (2010), who observed salmonella of beef sausage was (20\%).

\section{CONCLUSION}

The findings of this study revealed that, chemical composition for ostrich sausage was the highest percentage in crude protein, Ash and total energy expenditure of fat while beef sausage was the highest percentage in moisture. For microbiological load, beef sausage showed the highest count in all microorganisms which included in the study except total coli form and Pseudomonas were not detected in sausages. The salmonella was not detected in ostrich sausage, while it was detected in beef sausage.

\section{Recommendation}

- It is strongly recommended to use ostrich meat for sausage processing.

- Promotion programs are needed to make ostrich meat products more acceptable to consumers.

- Control of E.coli and other food-borne pathogens such as Salmonella and Staphylococcus aureus can be achieved. Precautions should include adequate cooking and avoidance of cross contamination of cooked meat by contaminated equipment, water or infected food handlers.

\section{DECLARATIONS}

\section{Corresponding Author}

E-mail: yahilal@gmail.com; ORCiD: 0000-0002-7298-6169

\section{Authors' Contribution}

All authors contributed in research conduction, analyzing and writing, equally.

\section{Conflict of interests}

The authors declare that they have no competing interests.

\section{REFERENCES}

A.O.A.C. (2002). Official method of analysis. Association of Official Analytical chemist. Horwitz, W. (ed), Washington, DC, USA. https://www.aoac.org/official-methods-of-analysis-21st-edition-2019/

Alamin SAE (2015). Sausages some quality attribute. American International Journal of Research in Humanities, Arts and Social Sciences, 12: 39-43. http://iasir.net/AIJRHASSpapers/AIJRHASS15-723.pdf

Antunes IC, Ribeiro MF, Pimentel FB, Alves SP, Oliveira M, Bessa R, and Quaresma M (2018). Lipid profile and quality indices of ostrich meat and giblets. Poultry Science, 97(3): 1073-1081. https://doi.org/10.3382/ps/pex379 I Google Scholar

Atef AA, Nahed MA, Amr A, and May MA (2015). The effect of arak stems extracts on chemical characteristics, bacterial activity and sensory evaluation of beef sausage products. International Journal of Advances in Agricultural and Environmental Engineering (IJAAEE), 2: 39-43. https://scholar.google.com/citations?user=rY9dYwIAAAAJ\&hl=en Google Scholar

Babiker SA, and Lawrie RA (1983). Post mortem electrical stimulation and high temperature aging of hot deboned beef. Meat science, 8(1):1-20. https://doi.org/10.1016/0309-1740(83)90028-1 I Google Scholar

Cooper RG (1999). Ostrich meat, an important product of the ostrich industry: a southern African perspective. World's Poultry Science Journal, 55: 389-402. https://doi.org/10.1079/WPS19990027 I Google Scholar

Food and Agriculture Organization FAO (2011). The state of food security in the world. Food and Agriculture Organization, Rome. http://www.fao.org/3/i2330e/i2330e00.htm I Google Scholar

Hamad NMH (2000). Prevalence of Escherichia Coli, salmonella and staphylococcus aureus in processed meat in Khartoum State. University of Alnileen .Khartoum. Sudan. http://khartoumspace.uofk.edu/handle/123456789/9296

Hasan Hussein F, Razavi S, Emam Djomeh Z (2019). Evaluation of physicochemical, sensorial and microbiological attributes of fermented camel sausages. Iranian Journal of Chemistry and Chemical Engineering (IJCCE), 38(2):171-181. http://www.ijcce.ac.ir/article_30665_d6ca3ba13cb406fe761526883c62bc28.pdf I Google Scholar

Hoffman LC, Joubert M, Brand TS, and Manley M (2005) .The effect of dietary fish oil rich in n-3 fatty acids on the organoleptic, fatty acid and physicochemical characteristics of ostrich meat. Meat Science, 70: 45-53. https://doi.org/10.1016/j.meatsci.2004.11.019 I Google Scholar

Honkel KO (1998). Reference method for the assessment of physical characteristics of meat. Meat Sciences, 49: 447-457. https://doi.org/10.1016/S0309-1740(98)00034-5 I Google Scholar

Ibrahim S (2008). Utilization of wheat germ flour in the processing of sausage. M.Sc. thesis in meat technology. Khartoum University, Sudan. Link I Google Scholar 
Mohammed RA, (2009). Quality evaluation of beef sausage incorporated with bee honey. M.Sc. thesis in meat Technology. Khartoum University, Sudan. Link I Google Scholar

Sales J and Horbanczuk J (1998). Ratite meat. World's Poultry Science Journal 54: 59-67. https://doi.org/10.1079/WPS19980005 I Google Scholar

Sales J, Horbanczuk JO, Dingle J, Coleman R and Sensik S (1999). Carcass characteristics of emus (Dromaius ovaehollandiae). British Poultry Science 40, 145-147. https://doi.org/10.1080/00071669987999 I Google Scholar

Snedecor GW, Cochran WG. (1980). Statistical method $7^{\text {th }}$ Ed. The lowa state university press, Ames, lowa, USA. 1980:39-63. Google Scholar

Steven ML, David GT, and Dennis NM (2019). Chapter 14 - sausage processing and production Editors: Steven M. Lonergan, David G. Topel, Dennis N. Marple, The science of animal growth and meat technology (second edition), Academic Press, Elsevier Inc. Pp. 229253. https://doi.org/10.1016/B978-0-12-815277-5.00014-7 Link

Zdanowska Sż, Marchewka J, Horbańczuk Jo, Wierzbicka A, Lipińska P, Jóźwik A, Atanasov AG, Huminiecki Ł, Sieroń A and Sieroń K, (2018). Nutrients composition in fit snacks made from ostrich, beef and chicken dried meat. Molecules, 23: 1267.

https://doi.org/10.3390/molecules23061267 I Google Scholar 